\title{
THE APPROPRIATE TECHNIQUE IN ENHANCING STUDENTS' CAPABILITY IN SPEAKING ENGLISH
}

\author{
${ }^{1 *}$ Gusti Milla Quaidy and ${ }^{2}$ Haykal Alpard \\ 1,2 English Education Department, IAIN Bukittinggi, West Sumatra, Indonesia \\ *Corresponding author: gustimillaquaidy@gmail.com
}

\begin{abstract}
Currently, learning English cannot be separated from the classroom process. By learning English, students will be easier to communicate and compete to other students over the world. It happens because English has been existing as the international language used by almost whole people in the world. Related to learn English, there are four skills in English, they are listening, speaking, reading and writing. By considering those skills, speaking is the skill that shows the product during learning English. Unfortunately, numbers of students are lazy to speak because of the anxiety. The anxiety can set the students being unconfident to produce their oral communication. According to Hammer Communicative Language Teaching (CLT) is the name which was given to a set of beliefs which included not only about what aspects of language to teach, but also a shift in emphasis in how to teach. based on the expert findings. Therefore, this paper is proposed to resolve the problem happened by giving the appropriate technique to this case.
\end{abstract}

Keywords: English, students, learning, speak.

\section{Introduction}

In learning English, students are expected to be able in speaking. It makes students being easy to communicate each other. Students are hoped to be able in comprehending the meaning of each speakers and to be confidence to speak to everyone. Unfortunately, some students are afraid to communicate by using English to each people. Those students just focus in grammar so that the students do not want to show. By looking at the problem appeared, It happens because the teachers only ask the students to have capability in structure so that the students will think before they want to speak. It makes the students unconfident to speak. Hence, to get students' interest in speaking, teachers must find the appropriate method in teaching English. Related to the appropriate methods, Communicative language teaching (CLT) is one of the appropriate method to get students' interest in speaking because students' who are not comfort in learning, they will not concern to study. According to Rusnawati stated in Brown (2007:218) theory of communicative competence that consists of the interaction of grammatical, psycholinguistic, sociolinguistic, and probabilistic language components. Therefore, utilizing the enjoyable method is the best way to solve the problems. 
Proceedings of the $1^{\text {st }}$ Annual International Conference on Language and Literature, 18-19 April 2018, Fakultas Sastra, UISU, Medan, Indonesia.

\section{Literature Review}

\section{Communicative Language Teaching}

Communicative language teaching is one of the suitable method that has been using by some teachers. It happens because the method involves the students to be interactive during learning process. Larsen and Anderson Stated that Communicative Language Teaching (CLT) aims broadly to make communicative competence the goal of language teaching (2011: 152). Additionally, Horwitz (2008) also has stated that CLT teachers tend to communicate in target language and the teachers do not accept the students' answer by using the students' first language, while direct method and natural approach teachers emphasize listening and reading.

Accordingly, .... by using CLT in teaching-learning speaking compared to other approaches. They further state that through this approach, a teacher helps to motivate her learners to work with the language through trial and error. They are expected to interact with each other, individually or in pairs or in group work (Jannah, Azis, and Yasin, EEJ, 2017). It tells that the method involves the both students and teachers to be creative. So, this method is necessary to be applied while learning process by teachers.

\section{Research Method}

This study was conducted by using qualitative approach which used to see the effect of using CLT as the method in speaking learning process. The method guides the students more active because it involves the students to speak up. The researcher conducted the classroom observation by asking the students to do speaking task by writing the task first and by asking the students to do speaking task by speaking directly. In doing the task by speaking directly, the students are asked to answer the teachers' question directly without thinking. It is more effective than by asking the students doing the task by writing what they want to say first. When the teachers ask the students do their assigment by writing in a paper first, It makes the students getting a bit stress. It happens because the students have to memorize what they want to say.

Therefore, based on both observation, researcher points that by asking the students to do the speaking task by answering the teachers' question directly is more effective than by asking the students to do speaking task indirectly because one of the CLT's ways in teaching speaking English is to make the students interactive. It based on Horwitz (2008) also has stated that CLT teachers tend to communicate in target language and the teachers do not accept the students' answer by using the students' first language, while direct method and natural approach teachers emphasize listening and reading.

\section{Discussion}

\section{Function}

CLT has been recomended method to teachers to teach students especially to improve the students' speaking ability. It occurs because by applying CLT as the classroom teaching method, the students will be asked to be 'talkative' by the teachers so that it 
can enhance students being confident to speak English in front of the people. The method is chosen because There are lots of problem happen that make the students are not able enough in speaking, such as unconfident, lack of vocabularies, unknown pronouncing words, etc. There are two functions in applying CLT as the speaking learning method:

1. Active learners

Speaking learning will order the learners to be more 'talkative'. It means that the learners may not be passive in learning. The learners have to be involved to do several activities in the classroom that can make the learners speak and mingle to around them during speaking learning process. According to Richards "Communicative language teaching sets as its goal the teaching of communicative competence". Communicative competence means that the teacher have to be able to make the students acquiring the language to be able using the language to communicate each people. Being able to use language means that the learners have to know the purpose what they want to say. Therefor, CLT will make the students being active during classroom process.

\section{Social Learners}

Futher function in applying CLT as the method during speaking learning is the learners will be able to interect to their collegues. It happens because the learners will be asked to do group or pair learning. It cannot be independent. Accordingly, this method also teach the learners to be able to interect each other.

\section{The Apllication of Communicative Language Teaching}

Applying CLT in classroom is not really difficult because the teachers only need to have idea to create the appropriate technique in teaching speaking to the learners. One of the techniques is gaming. The game can be used in learning process by combining the speaking material, for instance the teachers give whisper game to the learners. The learners will play the game by collaborating to each collegues so that it can make the students being active. Thus, to apply CLT as the speaking learning method is not difficult.

\section{Conclusions}

This study shows that based on the fact, CLT can give the solution to make the students being enjoy while they are in speaking learning class. Most of students are still afraid to speak up because the students are lack of motiavtion during learning process. The students only focus on grammar, fluency, and vocabulary. The expert has stated that this method is really recommended to teach students to be an active learners. Accordingly, the assumption that speaking is a bit difficult can be solved by applying this method to teach students.

\section{References}

Brown, douglas (2000). teaching by principles. California Harmer, Jeremy, the practice of english language teaching, Cambride, UK Jannah, Aziz, Yasin (2017). Communicative Language Teaching (CLT) For Teaching Speaking, English Education Journal (EEJ) 